\title{
DEBATE
}

\section{HIV TESTING AND ARV PROPHYLAXIS FOR NEWBORNS WITHOUT THEIR MOTHERS' CONSENT}

\author{
Matthew Chersich, MB BCh, MSc (Public Health), PhD \\ International Centre for Reproductive Health, Mombasa, Kenya \\ Marlise Richter, BA Hons, MA, LLM \\ School of Public Health, University of the Witwatersrand
}

Criminal law, constitutional rights and medical ethics (not forgetting common sense) can at times contradict each other, putting medical professionals on the spot.

\section{CASE STUDY}

A paediatrician is called to the nursery ward of a government hospital to see a male infant born 8 hours previously. The infant's mother is 33 years old, wasted and has oral thrush. This is her second child, the first having died in infancy after a short illness with a history typical of pneumonia.

The mother was not offered an HIV test during pregnancy as the clinic she attended did not have such services. A nurse calls the paediatrician as her offer of HIV testing to the mother has been declined. She requests the paediatrician to convince the woman to test, given the benefits that such knowledge gives the woman, as well as to enable the provision of postexposure prophylaxis for the newborn and of infant feeding counselling. The paediatrician examines the newborn, who is vigorous, fully grown for age and has no signs of HIV infection. She then carefully counsels the patient, explaining the potential harm of testing, and the benefits of HIV testing, for the woman and her infant. The woman still declines.

The paediatrician is aware of the efficacy of antiretroviral (ARV) prophylaxis given to HIV-exposed newborns whose mothers did not receive ARVs. ${ }^{1-3}$ The former's

\section{DISCUSSION}

\section{AN ETHICAL AND RIGHTS-BASED APPROACH}

A woman's constitutional rights to privacy, reproductive choice and bodily autonomy are all too often violated and require adequate legal protection. Also, a woman's right (and legal obligation) to make choices for her child is common practice. However, HIV infection in infants and its concomitant cost and suffering are essentially
This article is based on a case study discussed on the HIV Policy \&t Ethics Discussion Forum: http://groups.google. com/group/policy-ethics.

conscience and medical duty to act in the best interests of her patient (the child) have to be balanced against hospital and international policies which state that newborns cannot be tested for HIV exposure and be given prophylaxis without their mothers' consent. She thinks of many other colleagues - such as the previous medical superintendent of the East London Hospital Complex ${ }^{4}$ - who in similar situations acted from their conscience, even if such actions were contrary to prevailing policies and protocol. The paediatrician then tests the infant, whose antibody rapid tests show he is HIV-exposed. The doctor provides ARV prophylaxis to the infant, counsels the woman about her own HIV status and enrols her in an HIV clinic which provides antiretroviral treatment (ART).

\section{Questions for discussion}

1. Was the paediatrician correct to test the infant without the mother's consent? What is the optimal balance between a woman's right to autonomy and choice, and her infant's access to health care services?

2. Was the paediatrician correct to provide ARV prophylaxis to the infant without consulting the mother? Should the paediatrician have informed her that she had given the infant ARV prophylaxis?

preventable. In such circumstances, rights compete and need to be carefully weighed. Dedicated efforts, which are culturally appropriate and, ideally, communicated in patients' home language, are needed to explore and address the underlying reasons why the woman declined HIV testing. In South Africa, ART is becoming increasingly available, and systems are in place to safeguard confidentiality. In such settings, it is difficult to construct a reason for not testing an infant; when the mother refuses, that is more compelling than an HIV-free child. 
This does not discount the fear of knowing one is HIV infected, nor the potential for violence following disclosure of HIV status to one's partner.

Mandatory testing of newborns could signify the beginning of a slippery slope, potentially eroding the right to refuse testing in situations such as pregnancy, post-rape, pre-marriage, post-occupational injury, or even among couples in general. ${ }^{5}$ In itself, a desire not to engage in a 'slippery slope' argument is an inadequate rationale for not choosing between the child's best interests (identifying exposure and receiving ARV post-exposure prophylaxis) and a woman's interests in not knowing her own HIV status. Although legislation, ${ }^{6}$ policy, and guidelines ${ }^{8}$ emphasise the principle of informed consent, the Constitution trumps these. Section 28 of the Constitution states: 'A child's best interests are of paramount importance in every matter concerning the child.' This clause has been used to assert children's best interests, as in cases where Jehovah's Witnesses declined blood transfusions for their children.

Where current practice conflicts with the child's interests, can health care workers act from their conscience, or is this the sole domain of the courts? Where policy and legislation are outdated and lag behind medical progress, bringing a test case to court could precipitate change. For example, in circumstances where a woman refuses HIV testing after birth, a health care worker could launch an urgent court application to test the infant and provide prophylaxis without the woman's consent. The authors feel that the matter of a paediatrician launching such a case is long overdue. It could be argued that paediatricians each day make active decisions not to test newborns for HIV exposure, even though testing may be in the best interests of those whom they serve.

Several states in the USA have for almost a decade successfully implemented mandatory testing of newborns and thus provided proof of concept and encouraging safety data; this should justify further investigation in the South African context. ${ }^{10}$ The state must assume ultimate responsibility for protecting children's health and wellbeing, and should intervene when these are undermined. Another consideration is that children who have contracted HIV could in time argue that, by not having been tested for HIV exposure at birth, the health providers who cared for them after childbirth neglected to protect them from HIV infection and did not act in their best interests.

\section{LEGAL IMPLICATIONS}

In the above scenario, it is doubtful that the woman would institute legal action against the pediatrician; but if she were to do so, the legal ramifications for this case study would be essentially threefold:

1. Any invasive medical treatment or test without the patient's consent (in this instance, that of the legal guardian of the infant - her mother) constitutes an assault under South African common law as well as an invasion of personal rights. ${ }^{11,12}$

2. It therefore follows that the mother could lay a charge of assault on behalf of her child against the doctor who tested and provided medical treatment to the infant without the mother's consent.

3. The mother would also be in a position to report the paediatrician to the Health Professions Council of South Africa (HPCSA) for unethical conduct.

However, it is unlikely that such a course of action would succeed in court. In her defence, the paediatrician would be able to argue that the court is under a constitutional obligation to develop common law so as to '... promote the spirit, purport and objects of the Bill of Rights' (section 39(2) of the Constitution) and in line with the paramount place given to the interests of the child (section 28(2) of the Constitution).

Evidence is overwhelming that it is not in the best interests of a child to acquire HIV from the mother, and that providing HIV testing and post-exposure prophylaxis will reduce the risk of the child contracting a chronic and life-threatening illness. Moreover, medical evidence shows that administering a single dose of ARVs to an infant is not harmful. ${ }^{13}$

The paediatrician could therefore argue that courts are constitutionally obliged to develop the common law of assault to exclude instances of beneficent intervention in the interests of a minor. With this approach, it is likely that the doctor would be acquitted of a charge of assault, while the Health Professions Council would probably make a similar finding.

\section{CONCLUSION}

A test case may effect policy change, though must never negate or minimise the real difficulties that women face in this epidemic, and their needs for care and support. Ideally, women should be strongly encouraged to test and be referred to appropriate programmes during or prior to pregnancy. In lieu of this, the infant's interests in not contracting HIV are paramount.

Perhaps the epidemic could be reversed with more vigorous interventions, carefully considered and with specific efforts to minimise any human rights infringements. Where access to HIV treatment and confidentiality are assured, the degree and range of benefits of an early HIV diagnosis differ markedly from those of a late diagnosis when HIV inevitably declares itself with severe diseases. Perhaps health workers have for too long protected people from facing an inevitable diagnosis, rather than protecting adults' health and that of their children. We can never turn back the clock, but we can alter the speed of its ticking.

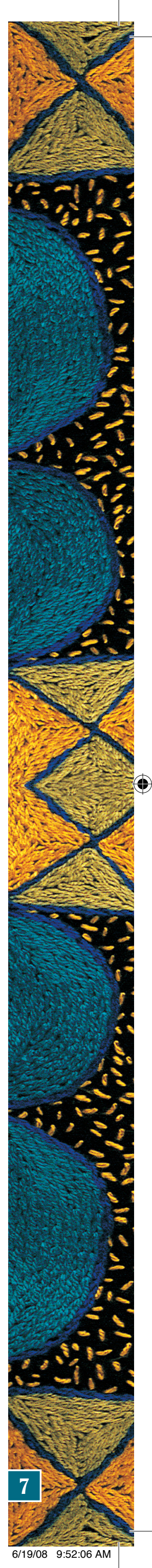


REFERENCES

1. Gray $G E$, Urban $M$, Chersich $M F$, et al. A randomized trial of two postexposure prophylaxis regimens to reduce mother-to-child HIV-1 transmission in infants of untreated mothers. AIDS 2005; 19(12): 1289-1297.

2. Wade NA, Birkhead GS, Warren BL, et al. Abbreviated regimens of zidovudine prophylaxis and perinatal transmission of the human immunodeficiency virus. $N$ Engl J Med 1998; 339(20): 1409-1414.

3. Taha TE, Kumwenda NI, Hoover DR, et al. Nevirapine and zidovudine at birth to reduce perinatal transmission of HIV in an African setting: a randomized controlled trial. JAMA 2004: 292: 202-209.

4. Ndou C. Doc who supported Nozizwe suspended. Mail \& Guardian 2007; 14 August.

5. Venter FW. Make HIV tests compulsory for South Africans. Sunday Times 2007; 3 June.

6. The National Health Act, 2003. Pretoria: Government Printer, 2005.

7. National Policy on Testing, 2000. Pretoria: Department of Health, 2000

8. The Management of Patients with HIV Infection or AIDS. Pretoria: Health Professions Council of South Africa, 2007.

9. Venter Z. Doctors go to court to get blood for baby. IOL 2005; 25 October.

10. Susman E. Despite the controversy, HIV prenatal testing laws get the job done. AIDS 2001; 15(14): N15-16.

11. Stoffberg v. Elliott 1923 CPD 148

12. Castell v De Greef 1994 (4) SA 408 (C)

13. Mofenson $L M$, Munderi $P$. Safety of antiretroviral prophylaxis of perinata transmission for HIV-infected pregnant women and their infants. J Acquir Immune Defic Syndr 2002; 30(2): 200-215.

\section{REBUTTAL}

\section{COERCIVE POLICIES DO NOT MAKE FOR BETTER HEALTH OUTCOMES}

Fiona Scorgie, BA Hons, $M A, P h D$

Gender AIDS Forum, Durban

Beth Ann Filiano, MPH, MPhil

Mailman School of Public Health, Columbia University and Gender AIDS Forum

Katharine Shapiro, $P A, M P H$

Consultant, New Delhi

As it stands, this argument for mandatory newborn testing unnecessarily pits the interest of mother and child against each other and creates conflict where there should be collaboration. Our main concern is that it fails to acknowledge the consequences of the fact that newborn testing amounts to 'proxy testing' of the mother - in this case, without her consent. Not only do the paediatrician's actions violate the mother's right (and indeed legal obligation) to make medical decisions for her minor infant, they also violate her constitutional rights to privacy, reproductive choice and bodily and psychological integrity. ${ }^{1}$ The policy change that Chersich and Richter are urging would disempower and undermine women's agency on a number of levels. Further, proxy testing of the mother in this way is a violation of fundamental rights that are now recognised and widely accepted as necessary components of ethical HIV diagnosis and treatment. These include the right to informed consent and not to be tested against one's will. Such rights are enshrined in both national and international policy, guidelines and legislation ${ }^{2,3}$ and - perhaps most importantly - the South African HIV \& AIDS and STI National Strategic Plan 2007 - 2011. ${ }^{4}$ They are also recognised internationally as good public health practice by WHO and UNAIDS. 5,6

The authors admit that mandatory testing could prompt an 'eroding [of] the right to refuse testing in [other] situ- ations.' Yet they seem reluctant to fully engage with this danger. The acts of testing and administering medication to an infant without its mother's consent are but a small step away from forcing all pregnant women to test for HIV, and if they test positive, to compel them to take nevirapine or AZT before they give birth. Indeed, some bioethicists are already making this argument. ${ }^{7}$ But further dangers lurk on this slippery slope. Ignoring the mother's rights and autonomy in the name of acting 'in the best interests of the child' raises the spectre of a much more severe monitoring of pregnant women lest the infant suffer harm (e.g. ensuring that they do not smoke, use alcohol and drugs, or exercise too vigorously). Such 'monitoring' would erode decades of progress made in the field of women's reproductive health and rights. It would also take us back to an earlier era in which women were regarded as little more than conduits for healthy babies.

Although we agree that more culturally sensitive efforts are needed to better understand the reasons why women in such situations may decline testing, much of this is already known. There has been extensive social science research on stigma, denial and blame in the epidemic - and on the role that gender plays in the particular configurations of these collective responses..$^{8-11}$ We also know from studies of HIV disclosure, for example, that the diagnosis itself is still received by many with profound dread. Suicide ideation following a positive diagnosis is common. ${ }^{12}$ But it remains the case that women, in particular, bear the brunt of this stigma: they are often blamed for bringing HIV into the home or into a relationship, they face the very real danger of being beaten by an abusive partner, abandoned, shunned, ejected from the home and rendered destitute. ${ }^{13-15}$ These are not uncommon consequences of the abjection that HIV continues to signal for many people, and which makes an HIV diagnosis something to fear and avoid, both for the individual concerned and for the wider community in which they live. Notwithstanding the limited gains made in reducing stigma in recent years, we should not mandate proxy HIV testing for women unless these issues have been more fully addressed.

The woman in the case study cited above may be faced with further challenges. Her own health seems precarious and after giving birth, she might not have had the emotional or physical resources to cope with a positive HIV diagnosis, much less to deal with the implications of her child receiving antiretroviral prophylaxis. Under such circumstances, what chance does the health of the infant have? With no acknowledgement of the known relationship of infant survival to its mother's wellbeing and survival, the debate is reduced to a simplistic contest between mother and baby. Yet a newborn does not exist in a vacuum; the mother's health and wellbeing are central to efforts to improve infant health. ${ }^{16-18}$ Furthermore, the paediatrician may have conflicting moral obligations 
between baby and mother, but the hospital itself has an obligation to both the mother and the baby. One cannot be ignored at the expense of the other.

This raises a further concern for us. The case study notes that 'the mother was not offered an HIV test during pregnancy as the clinic she attended did not have such services.' This suggests that the problems need to be addressed upstream, with a particular focus on prongs 1 and 2 of the World Health Organization prevention of mother-to-child transmission (PMTCT) strategy. ${ }^{19}$ Thus the first points of intervention would be: helping women in high prevalence regions to assess their own risk of infection, empowering them with knowledge to protect themselves, preventing unintended pregnancy in women with HIV, and making safe abortion readily available. Then we would need to ensure that all antenatal clinics do have VCT services - and that the quality of counselling and follow-up support is high, so that more women choose to be tested during pregnancy and enter PMTCT programmes if necessary. Community-based interventions, in particular 'mother-to-mother' support groups or one-on-one counselling, are powerful and effective. ${ }^{20,21}$ We suspect that the woman in the case study might have responded differently if she had been counselled by a peer who shared her language and cultural background, and who had perhaps been through similar experiences herself. This would have been preferable to being 'convinced' to test in a time of stress where informed consent could not be assured and thus was ignored by a paediatrician whose main concern was clearly the health of the infant. Moreover, consent is important not only from a human rights perspective but also from a medical point of view: when people's choices are disregarded and when their buy-in is not secured, treatment and follow-up may be compromised. Bringing a test case to court could potentially undermine precisely the purpose it is meant to serve, namely protecting the health of infants. It could also have longer-term public health consequences, since this kind of legal action could deter vulnerable women from seeking out antenatal care at all. The policy and legislative changes proposed by the authors, we argue, are premature if not completely unnecessary.

The authors posit that '[p]erhaps the epidemic could be reversed with more vigorous interventions ...'. We agree that the severity of the South African epidemic calls for firm and decisive intervention. But we should not forget that an estimated $85 \%$ of HIV in this country is transmitted through heterosexual intercourse. ${ }^{4}$ Recall that the policy of mandatory newborn testing is intended to address the category of women who don't know their HIV status at time of giving birth yet refuse testing, both for themselves and for their infant. In turn, it is presumed that this policy would ultimately ensure that mother-tochild transmission is virtually eliminated. But in reality the numbers of women who fall into this category (of refusals) is likely to be very small. Indeed, there is evidence that with high-quality counselling, uptake of VCT among women in antenatal settings is very high. ${ }^{22,23}$ In fact, this vital information is central to the debate - yet the authors make no mention of it. Why, then, the need for a measure as coercive as mandatory newborn testing, enforced by law and policy, when the overall impact of this intervention on the HIV epidemic is likely to be relatively negligible?

Finally, for the authors to invoke the argument about health care workers' conscience is to assume that decisions made from 'conscience' will, in every case, align with what is medically the best decision to make for the patient. But this surely cannot be the case. We have only to consider a comparable situation relating to the implementation of termination of pregnancy policy in South African public health facilities. Here, too, we find health workers acting on the grounds of 'conscience' and refusing to have any part in carrying out the procedure. But many of these health workers also refuse to arrange adequate counselling or referral for the women concerned. Acts of 'conscience' are admirable, indeed. But they are hardly neutral, objective or necessarily medically correct.

In conclusion, we regard this argument as a classic example of 'act first, think later'; a narrow, biomedical and legal solution to a complex human problem. We are a long way from ensuring quality services for HIV-positive women and protecting their rights to information, privacy and confidentiality. Our view is that women should not have to pay for the failures of primary HIV prevention and reproductive health services, nor should their rights be sacrificed because political commitment and leadership in the epidemic has been lacking. In short, more debate is needed - and we would urge that such debate involves a wide range of stakeholders: not only maternal and child health specialists and bioethicists, but also experts and advocates in the fields of women's reproductive health and rights, AIDS activists, civil society organisations, social scientists, and representatives of government. Most importantly of all, we need to hear the voices of ordinary women in South Africa who are actually confronted with such painful dilemmas every day.

REFERENCES

. South African Constitution, 1996. Chapter 2 (Bill of Rights), sub-sections 12 and 14.

2. Health Professions Council of South Africa. Guidelines for the management of patients with HIV infection or AIDS; 2002. http://www.hpcsa.co.za/hpcsa/ UserFiles/File/Booklets/Booklet\%208\%20HIV.pdf (accessed 14 April 2008).

3. South African Department of Health. Draft national policy on testing for HIV; 1990. http://www.doh.gov.za/aids/docs/policy.html (accessed 14 April 2008).

4. The HIV \& AIDS and STI strategic plan for South Africa (NSP 2007-2011); 2007. http://70.84.171.10/ etools/doh/strat-plan/hiv-aids1.pdf (accessed 14 April 2008).

5. Jurgens R. Increasing Access to HIV Testing and Counseling While Respecting Human Hights. Background paper. New York: Public Health Program of the Open Society Institute, 2007.

6. UNAIDS, WHO. UNAIDS/WHO Policy Statement on HIV Testing; 2004. http://www. who.int/hiv/pub/vct/en/hivtestingpolicy04.pdf (accessed 14 April 2008).

Schuklenk U, Kleinsmidt A. Rethinking mandatory HIV testing during pregnancy in areas with high HIV prevalence rates: ethical and policy issues. Am J Public Health

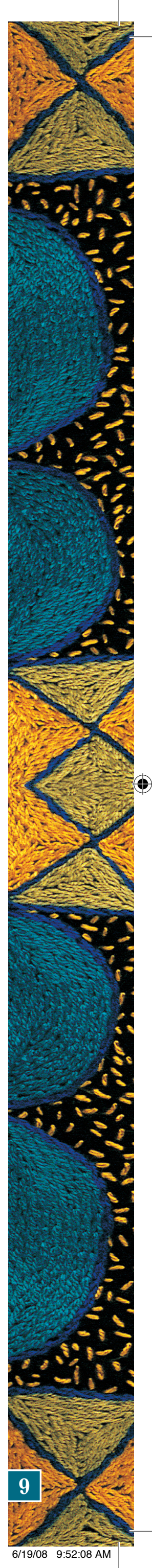


2007; 97(7): 1179-1183.

8. Campbell C, Nair Y, Maimane S. AIDS, stigma, sexual moralities and the policing of women and youth in South Africa. Feminist Review 2006; 83: 132-138.

9. Delius $\mathrm{P}, \mathrm{Glaser} \mathrm{C}$. Sex, disease and stigma in South Africa: historical perspectives. African Journal of AIDS Research 2005; 4(1): 29-36.

10. Lawless S, Kippax S, Crawford J. Dirty, diseased and undeserving: the positioning of HIV positive women. Soc Sci Med Nov 1996: 43(9): 1371-1377.

11. Skinner D, Mfecane S. Stigma, discrimination and the implications for people living with HIV/AIDS in South Africa. Journal of Social Aspects of HIV/AIDS 2004; 1(3): 156-164

12. Squire C. HIV in South Africa: Talking about 'the big thing.' London and New York: Routledge, 2007.

13. Dunkle KL, Jewkes RK, Brown HC, Gray GE, McIntryre JA, Harlow SD. Genderbased violence, relationship power, and risk of HIV infection in women attending antenatal clinics in South Africa. Lancet 2004; 363(9419): 1415-1421.

14. Dunkle KL, Jewkes RK, Brown HC, et al. Prevalence and patterns of gender-based violence and revictimization among women attending antenatal clinics in Soweto, South Africa. Am J Epidemio/ 2004; 160(3): 230-239.

15. Vetten L. Bhana K. Violence, vengeance and gender. A preliminary investigation into the links between violence against women and HIV / AIDS in South Africa. Johannesburg: Centre for the Study of Violence and Reconciliation, 2001.

16. Nakiyingi JS, Bracher $M$, Whitworth $J A$, et al. Child survival in relation to mother's
HIV infection and survival: evidence from a Ugandan cohort study. Aids 2003; 17(12): 1827-1834.

17. Newell ML, Brahmbhatt $H_{1}$ Ghys PD. Child mortality and HIV infection in Africa: a review. Aids 2004; 18: Suppl 2, S27-34.

18. Newell ML, Coovadia H, Cortina-Borja M, Rollins N, Gaillard P, Dabis F. Mortality of infected and uninfected infants born to HIV-infected mothers in Africa: a pooled analysis Lancet 2004: 364: 1236-1243.

19. WHO. Strategic approaches to the prevention of HIV infection in infants: report of a WHO meeting, Morges, Switzerland, 20-22 March 2002. http://www.who. int/hiv/pub/mtct/en/StrategicApproachesE.pdf (accessed 5 September 2007).

20. mothers2mothers. http://www.m2m.org/ (accessed 14 April 2008).

21. Coetzee D, Hilderbrand K, Boulle A, Draper B, Abdullah F, Goemaere E. Effectiveness of the first district-wide programme for the prevention of mother-to-child transmission of HIV in South Africa. Bull World Health Organ 2005; 83(7): 489494

22. Centers for Disease Control and Prevention. Introduction of routine HIV testing in prenatal care - Botswana, 2004. MMWR Morb Mortal Wkly Rep 2004; 53(46) 1083-1086.

23. Urban M, Chersich M. Acceptability and utilisation of voluntary HIV testing and nevirapine to reduce mother-to-child transmission of HIV-1 integrated into routine clinical care. S Afr Med J 2004; 94(5): 362-366.

\section{HIVIAIDS in South Africa}

\section{SAMA Member Price: R360.00 Non-member Price : R400.00}

ISBN: 9780521616294

This definitive textbook covers all aspects of HIVIAIDS in southern Africa, from basic science to medicine, sociology, economics and politics. It has been written by a highly-respected team of southern African HIV experts and provides a thoroughly researched account of the epidemic in the region. The book comprises eight sections, the first of which covers the numbers behind the epidemic, both as evolution and in their current state. This is followed by sections on the science of the virus, including its structure, diagnosis and spread. HIV risk factors and prevention strategies, focal population groups and the impact of AIDS in all aspects of South African life are discussed in the following four sections. The final sections examine the treatment of HIV and AIDS, the politics of AIDS, mathematical modelling and a discussion on the future of AIDS in South Africa.

This text has been written at an accessible level for the general reader, undergraduate and postgraduate students, health care providers, researchers and policymakers in this field as well as international scholars studying HIVIAIDS in Africa.
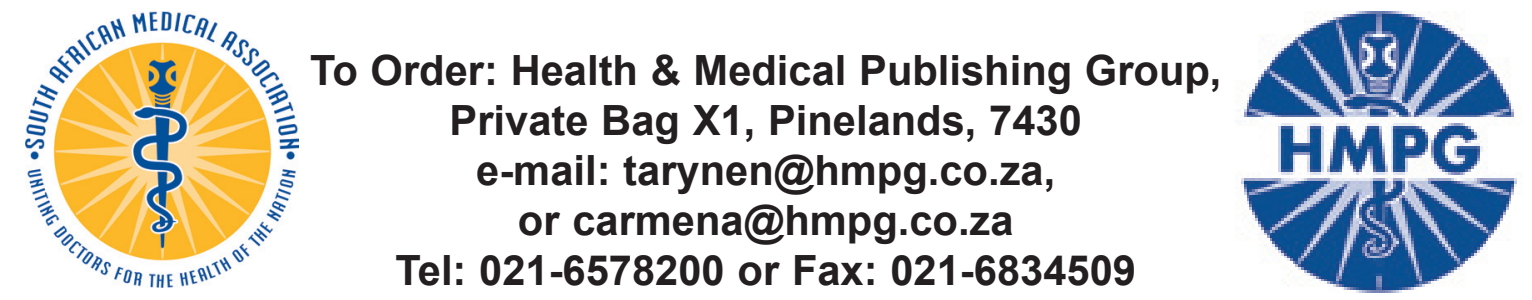